\title{
Political Participation Of The Chinese Youth In Market Economy And Implication On Communist Youth League
}

\author{
Dr. Rakesh Kumar \\ Assistant Professor, Centre for Chinese \& South East Asian Studies, School Of Language Literature and \\ Culture studies. \\ Affiliation: Jawaharlal Nehru University, New Delhi-110067, India \\ Address: Center for Chinese \& South East Asian Studies, Jawaharlal Nehru University, New Delhi-110067, \\ India \\ Contact No: 0091-9911482779/9968433228(M), Residence: 011-26741822Office No: 011-26704653(D)/Ext: \\ 4653
}

\begin{abstract}
Political participation entails citizens' engagement to exert influence on the political process and policies in a desired direction. Therein, participation of the youth has significance as a transient yet constantly receiving community with potential to shape the course of history in any society. The activities and functions of youth organizations have been pivotal in effecting changes in the twentieth century Asian socio-political and economic realms. Under the similar circumstances, the People's Republic of China appears to be continuously evolving its social, economic, political and cultural regimes in response to the fluctuating demands of the citizens and the youth. This Essay fathoms changes in political participations of the youth in China, its implication on the Communist Youth League and how the Communist Youth League responds in the era of Market Economy.
\end{abstract}

Key Words: Political Participation, Youth, Market Economy, Communist Youth League

Academic Discipline: Sociology

Method/Approach: Historical Analytical Method

\section{Introduction}

The Communist Party of China made an epochal shift from a Planned Economy to that of Socialist Market Economy. As a consequence, China has deviated from its core guiding values i.e. socialist value and has started leaning on capitalist road. For instance, Communist China initiated land reforms beginning 1949 immediately after the liberation and establishment of new China and did propagate the policy of "land to the tillers". Following the socialist market economy, China has embarked upon snatching the land from the 'Have not's' and allowing the private firms to construct infrastructure for the 'have's' in the name of economic development. The fundamental question is how Communist Party of China is justifying its new move and how such regimes are perceived by its citizens? In this context, the role of the youth in China has significance as a transient yet constantly receiving community with potential to shape the course of its history and society. The activities and functions of youth organizations have been pivotal in effecting changes in the twentieth century Asian socio-political and economic realms. This Essay fathoms changes in political participations of the youth in China, its implication on the Communist Youth League and how the Communist Youth League responds in the era of Market Economy.

The Youth is a stage where one is neither a child nor an adult, usually sidelined and discouraged in policy making process for lacking maturity. The space for participation of Youths in the formal policy making process is negligible. Nonetheless, youths in China, as elsewhere are the constantly receiving community with full of vigor, zeal, grand vision of the future and impending policy makers. Their support and participation need to be sought at the time of implementation and execution of the policies.

Different countries and disciplines differ in determining the age group of the youth. Based on the census data from the National Bureau of Statistics and the situation of Chinese youth, the age group of the youth is defined as those from15 to 29 years old ${ }^{1}$. Therefore youth described in this paper refers to the age group between 15 to 25 years living in mainland, not including youth from Hong Kong, Macao special administrative regions and Taiwan province. There are various definitions of youth. Glen H. Elder Jr. biologically, "Youth is an avoidable period in the development of the individual between childhood and adulthood, but the content of youth as a stage is totally different". ${ }^{2}$ As defined by the Chinese dictionary, youths are bracketed as those between the age-group of 15 years to 25 years. There are over 1.8 billion young people in the world today, 90 per cent of whom live in developing countries, where they tend to make up a large proportion

\footnotetext{
${ }^{1}$ Jieying Xi, “ Introduction to Chinese Youth" in Jieying Xi, Yunxia Sun and Jing Jian Xiao(ed) Chinese Youth in Transition , Ashgate, Aldershot ,2006

${ }^{2}$ Glen H.Elder,Jr."Adolescence in historical perspective", in JosephAdelson(ed).Handbook of Adolescent in psychology, John Wiley and sons, New york,1980,pp.40-16
} 
of the population. There are more than 235 million youth in India and 225 million in China alone. The number of adolescents and youth today is at an all-time high, but that number might not increase in future seeing the trend of aging population across the globe. The proportion of young people is actually set to decline from 17.6 per cent in 2010 to 13.5 per cent in 2050.

Political Participation varies among individuals and across nations in terms of level, mode, and quality. The factors that affect participation or mobilization are political system, political culture and traditions, socio-demographic conditions, cognitive competence and so on. Youth participation is often used interchangeably with the term 'active involvement'. This means more than simply taking part in an activity. It refers specifically to the involvement in the process of identifying needs, exploring solutions, making decisions and planning action within communities and organizations that seek to support civil society. In relation to young people, youth participation is often regarded as the involvement of young people in decisions that are made that affect them.

\section{Impact of the Socialist Market Economy on the Chinese Youth}

1. It has greatly impacted the values, thought and attitude of the youth, resulting into diversification towards Utilitarianism, individualism, money worshipping etc; this has in turn, led difference towards political participation. Influence of Western thoughts practices such as, Hollywood movies, rock music, KFC was evident in the Chinese market creating disillusionment for the youth and thus, hampering the mental health of the Chinese youth.

2. The Market Economy has created the environment for the "Survival of the fittest phenomenon" where youth are finding it difficult to cope with the challenges of employment, which in turn has dampened the spirit of political participation among the Chinese youth. The statistic shows the total number of unemployed in China $9 \%$ is in the age group of 15 to 29 years. ${ }^{3}$

It is clear that after Tiananmen Square Incident, especially after the Deng Xiaoping historic "Southern sojourn" of 1992, the economic and social structure underwent rapid change; there emerged new issues with direct relevance for the survival of the youth. The youth could no longer rely on the participation mode/module such as mass protests, gathering and shouting slogans against the government and the Communist Party of China, which they had done after the beginning of the economic reform and opening up in the Tiananmen Square Incident of 1989. It was allowed and tolerated before as they helped the progressive section within the party to push the agenda of economic reform and consolidate power within the Party. But the youth protest of 1989 was seen as challenge to the authority of the party as it pushed for political reform that the Party was not ready to accept. Undoubtly, the socialist market economy provided multiple choices to release their energy, though it brought miseries for the other section of the people in China. The disinvestment of small or loss making SOEs (抓大放小) created a huge pool of the unemployed of which a large section was of the youth.

At the provincial and municipal levels, the political decentralization resulted in greater freedom of action and lessening of disciplinary control from the central government.The actors of the lower rungs of the ladder were able to work in their own interests. Following the reforms, the fiscal powers of the state were reduced, and the commercialization of the public administration and services was a response to this new situation. The local government set up a lot of agencies which charge fees for formerly free services. The Universities now started to charge for their courses .The schools and private colleges introduced enrolment fees. The hospitals sell their medicine at very high prices. ${ }^{4}$ In the health sector too, treatment and services became chargable, especially for the large population employed in the private sector. It also marked the beginning of total commercialization of all the social institutions of China.

A large section of the employees in the rapidly growing private sector were youth, who were attracted to the lucrative pay package and yet felt insecure without the safety net of the social institutions, which had been withdrawn by the State.

The socialist Market economy in China has created an environment of mistrust not only among the business community in China but it also has created mistrust among the Chinese society as a whole. It has promoted more and more Individualization of the Chinese society. The collective's values of the Chinese youth were in continuous decline due to the rising cost of living and flooding of utility commodities goods in the Chinese market. Due to increasing economic disparity, social relations were affected leading to the uncertainty and rise in crimes, especially juvenile crimes.

\section{Political participation of the Chinese Youth in the Market Economy}

The motives of political participation vary from person to person due to different socio-economic, political conditions of the society. In case of China, where it has 'Strong State', it becomes quite interesting to understand the status of Political participation among the most enthusiastic group i.e. Youth. How the Political participation has affected the state -society

3代小琳(Dai Xiaolin), 中国青年失业率 9\%攀新高 72\%失业者为长期失业 Zhongguo qingnian shiyelu 9\% pan xingao $72 \%$

shiyezhe wei changqi shiye The long term unemployment ratio of the youth has reached to a new height of $72 \%$ from 9\% [EB/OL]。

http//news.xinhuanet.com/fortune/2005-05/24/content_299434.htm.

${ }^{4}$ Rigas Arvantis, Pierre Miege and Zhao wei, “A Fresh Look at the Development of a Market Economy in China” China Perspectives, in http://Chinapaperspectives.revues.org/564 downloaded at 1:10pm on 16/2/2016 
relation in the period of Socialist Market economy and has impacted the youth? The age of the participants plays a very important role in the decision making on any issues. Since the beginning of economic reform, there is an increased political consciousness among the youth, especially among the University youth who are the most affected group as they enter the job market after their graduation from the university. They enter into world of challenges and have to look for their source of survival. Therefore, changes in the government policies directly affect the youth; who need to understand the challenges in the socio-economic context by exercising their political understanding of the situation. In other words, political consciousness needs to be translated into political participation so as to able to resolve concrete issues of life. With the introduction of the Socialist market Economy, multi-dimensional mode of participation emerged in China.

Understanding and studying the concept of class, ruling Party, nation, and the domestic as well foreign policy is the foundation of youth political participation. This knowledge helps them to analyse and form their own perspective. It can also be regarded as the first step towards political participation. Not only there are changes in the objectives of the political participation in the socialist market economy phase, this phase also witnessing a diversification of the mode of participation in China. To list few:

A. Membership of Political organization: Membership of any political organization is one of like Communist Party of China is one of the fundamental modes of participation; its objective is to interact with the masses and play an important role to influence the certain policies of the government having a bearing on youth.

As per the 2004 statistic of the Communist Party of China, total membership was 69.603million, among them 15.80 million were below the age of 35years which about $25 \%$ of the total membership of the Party ${ }^{5}$. Moreover, there is constant increase in the Party membership. There is also increase in the membership of the Communist Youth League. ${ }^{6}$

B. Direct participation in political activities: This refers to direct voluntary participation spirit through public election, revolt and other kind of channels. This is meant show their resentment. All these channel of participation was meant to be in consonance. For instance, Village level election, where people directly cast their vote to elect Local People Congresses.

C. Taking up important posts like becoming Civil servants by taking civil services Examination and becoming the part of any government body, where they can participate in the decision making or policy formation of the government. It is evident from the news by All China Youth federation News reported in 2009, that the number of youth taking the civil services examination had risen to $30 \%$ suggesting that the youth had no confidence in the industrial sector's ability to employ them. A total of one million youth took the examination on Sunday against 700,000 in 2008 . $^{7}$

D. The rich young entrepreneurs are forming lobbies or guilds to influence the government on certain policies which can directly benefit the business. After the Tiananmen Square Incident in 1989 China's agenda of Economic Reform and Open-door policy continued but with restrictions on mode of political participation. There came three challenges in front of the youth. Those are;

1. Managing life amidst rapid urbanization. 2 Employment choices amidst economic uncertainty 3 . Self-discovery amidst increasing professional demands.

These three issues were very important for youth as they had to, on one hand, start their family, and on other, progress in their professional life. To address these issues, there needed policies changes in favor of them, which prompted the youth to look for alternatives of the conventional mode of political participation. The market economy has produced many young entrepreneurs (Billionaires) such as Yu Minhong (俞敏洪) ${ }^{8}$, founder of the New Oriental Education and Technology

\footnotetext{
5 中国青少年发展状况 ---------统计数据 分析报告（2005）中国青年研究，2001（1） (Statistical data analysis report on status of China's youth development -------- (2005) China Youth Research ,2001(1)

${ }^{6}$ Data taken from 团史展览馆 ( League Historical Archive),http://www.gqt.org.cn/695/gqt_tuanshi/gqt_ghlc/tdjs/ accessed at 5:22pm on $15 / 6 / 16$
}

7 "Safety first: China youth rush to grab govt jobs" from All China Youth Federation News, December25, 2009 http://www.acyf.org.cn/2009-12/25/content_3315284.htm acessed on 28/1/17 at 3:23pm

8 俞敏洪(Yu Minhong); born 15 October 1962 in Jiangyin, Jiangsu) is the founder and current CEO of New Oriental Education \& Technology Group Inc. 新东方教育科技集团), and a member of the central committee of China Democratic League. As the owner of one of the largest private educational services, Yu is known as the "richest teacher in China", and "Godfather of English Training". ${ }^{11}$ On Hurun Report's China Rich List 2013, he had an estimated wealth $\$ 1.1$ billion and was ranked No. 245 on the list. 
Group, Ma Yun(马云) $)^{9}$ the founder and chairman of Alibaba Group and other billionaires and millionaires who formed a lobby to influence the policies of the government in their favor. The dominance and contribution of youth entrepreneurs forced the Communist Party of China to bring amendments in the constitution and include technocrats and entrepreneurs as the modern productive forces in the 1990s.

The scope of youth participation is getting broader day by day. The most important issue is corruption within the Party, corruption in Judiciary, Political system reform, economic structural reform etc. But nowadays, the youth are not only restricting them to the internal political changes directly affecting their rights but they are also closely monitoring the other political development in the globalized world. Such issues of their concern are international issue like America growing political might, post war Iraq reconstruction, terrorism problem, "bird flu" and so on. The advancement of technology has facilitated the active participation of the Chinese youth. Apart from the conventional sources of information like newspapers and television, they are also using the internet source to get first hand news and information's.

It is a fact that the youth participation in other areas are increasing at good speed, however, there is gradual decline in conventional political participation of the Mao era. The reasons for the decline of youth enthusiasm in political participation could have been many; however, the main reasons that appear are the following:

1. Youth have not always fully understood the Party's line and policies since the Third Plenum of the Eleventh Central Committee, and therefore lacks a firm political stand and convictions. Though the literacy rate of China is very high, but there were fewer takers of subjects like history, ideology and Marxism-Leninism theory class. There had been tremendous increase in the options in choosing courses in college as well as school level. Youth with the prime aim to go abroad prefer more international courses, which can offer those foreign visits and study? As the "Economy 'has taken over the politics in China, the mood of Youth too have shifted from Politics to economy.

2. Youth are unable to adjust fully to a complete social environment, and lack a scientific way of thinking. Reform and open policy have undoubtedly added vigor to China's economic development. However, it has broadened the complexity of China's social environment. The overlapping of old and new social structures, problems which have appeared in the course of reform, as well as the influx of western ideas and culture, together have posed a challenge to the youth. Youth failed to measure up in face of these challenges. Their ideological level was not satisfactory, and they adapted very badly. One very important reason was that their manner of thinking was not scientific. In their dealing with some questions, they had the following common features: they stressed the present and lighted the past to seek innovation and neglect heritage; in a lopsided effort, they tried to be different and discard common ground; and they were prone to make subjective rationalization and disregard objective reality.

3 . Academic institutions and academic curriculum had played a major role in forming different understanding among the Chinese students in particular and youth in general, For Instance, Some schools divide science and engineering majors and art and literature majors very early. Most science and engineering majors know little about history and culture, politics and economics. The educational structure is not favorable for strengthening love for the motherland, the people, socialism, and the Communist Party either in rational or emotional way. Growing up in the new society without any experience of the old one, and living in a new social environment has created much confusion in thinking, To promote superior academic performance primary and secondary schools seldom ask students participate in social activities or educate them in ideology and moral and ethical values system. Ordinary standards of civilized behavior, such as politeness and civility, discipline, and care of public property, should be matured in students during primary and secondary school, but are often left to be studies as "repeat course" in college and universities.

4. Although the present proportion of Youth League members among new recruits to college is as high as 90percent, their political awareness on the whole is poor. According to documented data, many high school graduates were admitted into Youth League just before the college examination, often just on the strength of teacher's recommendations; some of them did not even have the time to read the Youth League constitution. ${ }^{10}$ Mao Zedong Thought was the guiding ideology of Mao era when Chinese people, including the youth, were expected to adhere to this guiding ideology. With the demise of Mao Zedong, there appeared a lot of new guidelines, which was rather difficult for grass root cadres to understand; it failed to motivate young cadres towards the adequately to adapt to the new realities and challenges of fast changing social milieu.

5. The duality of the Party's perspective in Deng's China, i.e. "anti- right in Politics and anti-left in economy" had also puzzled Party's ideology instructors who could not always convince the young cadres to adjust to this

9 马云(Ma Yun); born September 10, 1964)is a Chinese business magnate and philanthropist. He is the founder and executive chairman of Alibaba Group, a family of successful Internet-based businesses. He is the first mainland Chinese entrepreneur to appear on the cover of Forbes .As of November 2014, he is the richest man in China (Hong Kong not included) and 18th richest person in the world, with an estimated net worth of $\$ 24.1$ billion, according to Forbes. https://en.wikipedia.org/wiki/Jack_Ma downloaded at $4 ; 39 \mathrm{pm}$ on $11 / 1 / 16$

${ }^{10}$ Yang JingYun, Li GongYi,et al, "Exploring the question of College students' Road of Growth”, Chinese Education, Vol.23.No.1 spring 1990. 
theoretical mismatched. ${ }^{11}$. The hope and romanticism of the young minds in $50 \mathrm{~s}, 60$ s came to be affected by the complexity of socio economic reality of the 1980s and 1990s. Moreover, exposure to the outside world brought the young minds face to face with numerous questions that could not be explained by using conventional framework.

The implementation of the Market economy and the insufficient human resource led Deng Xiaoping to invite the overseas Chinese student to return to China. He created an environment conducive for the people to return. During his southern trip in January 1992, he said that the government no longer cared what overseas students' political attitudes had been at the time of Tiananmen; he said, "They can all come back, after they return things will be well arranged. This policy cannot be changed." ${ }^{2}$ Unlike before 1992, when returnees were compelled to return to their original units, they now had much greater mobility and flexibility in choosing their work units. In March 1992, the Ministry of Personnel announced that family members could move to the cities where the returnees had found the job. ${ }^{13}$ And, on, 14 August 1992, a State Council notification announced new policies on passport and, most importantly, allowed returnee scholars to decide where they wanted to work. ${ }^{14}$

At the $14^{\text {th }}$ Party Congress, Jiang Zemin stated that "China Warmly welcomed people who are studying overseas to use various ways to express concern, support and to participated in the motherland modernization". ${ }^{15}$ The Third Plenum of the $14^{\text {th }}$ Party congress in 1993 put out a 12 Character slogan to direct overseas study "support overseas study, encourage people to return and give people freedom to come and go (来去自由)."16

During the early phase of socialist market economy, Communist Party of China came out with various liberal policies to attract the overseas Chinese talent. In order to promote world class technical education, The Party started providing preferential treatment to the foreign PhD's, which became the bone of as it led to protest and anguish among the young scholar trained within the country.

\section{Implication on Communist Youth League of China:}

While there is no doubt about the supremacy of the Communist Party of China, there existed various factions within the Party. These Factions had their own motives and strategies for further future development of China future. The most prominent are the 'Princelings' 'CYL' and 'Qing Hua' factions. Communist Youth League has diverse power that extends beyond the organization itself. In collaboration with the Party, it exercises leadership over the All-China Youth Federation, All China Students Federation and Young Pioneers of China ${ }^{17}$. The presence of factions in the Party, itself reflects the unofficial existence of interest groups that could actively participate in the contemporary politics of China. Earlier, the one and only mode of political participation of the youth was through Communist Youth League. The Communist Youth League

\footnotetext{
${ }^{11}$ Xue-liang Ding, "Disparity between idealistic and instrumental Chinese reforms” Asian Survey, Vol.28(II), November 1988, P.824

12叫郭正（Jiao Guozheng）,”碰破发展的出国留学工作”(Flourishing development of the work of sending out overseas students”), 中国高等教育 9Higher education in China, Beijing),No.12(1998), pp.6-8 in Higher Education in China, research materials from people's University,no.2,1999,p.72

13 “China to Improve Service for Returned Students,” Xinhua General News Service, March13, 1992.

14 “关于在外留学人员有关问题的通知”, (Notification on related questions concerning scholars overseas”), cited in David Zweig, Chen Changgui and Stanley Rosen, "Globalization and Transnational Human capital: Overseas and Returnee scholar to China*” The China quarterly,Vol.179,September 2004,p.739
}

15 For details please see October 12,1992 江泽民 Jiang Zemin 在中国共产党的十四次全国代表大会上的报告《<加快改革开放和 现代化建设步伐夺取有中国特色社会主义事业的变大胜利》 zai zhongguo gongchandang de (Jiang Zemin speech at the fourteenth party congress $<<$ Deepening of reform and modernization will bring great advantage in task of establishing socialism with Chinese Characteristics > Zhonggup gongchandang lici quanguaodaibiaodahuishujuku 中国共产党历次全国代表大会数据库(Data base of all previous Congress of the Party congress)http://cpc.people.com.cn/GB/64162/64168/64567/65446/4526308.html accessed at $5: 15 \mathrm{pm}$ on $15 / 4 / 16$

${ }^{16}$ Ibid.

${ }^{17}$ Wu Junfei, "Rise of the Communist Youth League" Economic and Political Weekly, March25,2006 
played a link between the Youth and the Communist Party of China. However, there has now emerged an alternative of Communist youth League in form of above mentioned organizations. Under the circumstances, it has become important to understand the relevance of the Communist Youth League in the changing socio-economic milieu of China.

Apart from this elite mode of political participation, there emerged other civil rights organizations like NGOs, GONGOs (government organized NGOs), Self Organized youth organizations (SYOs) and other small and big 'Grass root organizations, 18 . These new organizations that were helping the Chinese youth to convey their demands to the authority are acting as alternative to the Party's affiliated youth organizations i.e. Communist Youth League of China.

Grass Roots Organizations (草根组织) was a term adopted in the late 1990s when China's first group of the Non-Profit Organizations emerged. As mentioned above these 'grass root organizations' were different from the GONGOS as these organizations were autonomous and were not dependent on the government funding to carry out their work. As per the definition of the grass roots organizations, it can be divided into four categories:

1) Well-organized associations that represent their member's specific economic or social interests: These organizations were very few in numbers and were privately initiated chamber of commerce. However, they represent the country's most vibrant and increasingly crucial economic force, and their political influence has been growing rapidly. These private chambers of commerce were mostly located in the coastal regions of China. To name a few, they are 中城联盟 (biggest private association in the housing business); the president of the 中城联盟 Hu Baoxin wrote an “open letter" (公开信) and the other Real Estate Tycoon Ren Zhiqiang, the Chair of Real Estate Chambers of Commerce and the CEO of High profile Beijing real estate company, wrote a “万言书” which became famous as "Ren's ten-thousand -words statement" criticizing the government intervention in the housing market. It had great impact on the government policies. These kinds of the statement and open letter from the private association were a new phenomenon in China and provoked a heated debate among the public over the government's new policy.

2) Residents of the large cities have initiated autonomous organizations to support public interests such as the environment, education, human rights, public health and poverty alleviation. Liang Conjie(retired history professor at Beijing University) ,founder of Friends of nature, Wan Yanhai founder of a renowned NGO for AIDS education, graduated from the prestigious Fudan University Medical school with an M.D. in Public health, etc

3) Informally and loosely organized social/cultural networks based in urban communities and rural villages: vast numbers of the grassroots organizations have emerged in the urban communities and rural villages such as Beijing Opera fan, 拇指 民主（Thumb democracy） etc.

4) Students organizations, especially voluntary ones, on university campuses, were mostly confined to the campuses and mostly registered with the university administration. There were huge presence of the youth organization before the Tiananmen Square Incident; post- Tiananmen witnessed a decrease. It happened mostly due the economic growth and individual aspirations taking over the political ideologies which talks about the collectives values in the era of Socialist market economy.

The voluntary organizations were in rapid increase in China due to the growing economic gap between the rich and poor in the Chinese society in the socialist market economy phase. Yun Hanin in his research has defined the role and meaning of the voluntary organizations and volunteers engaged in China. He further gave the statistics of more than 30 foreign NGOs who have entered and has gained its ground in China through China International Centre for Economic and Technical exchanges and China Association for NGO Cooperation and spread its functioning to almost each and every part of China. ${ }^{19}$ These NGO projects are covering agricultural productions, drinking water, income generating activities, integrated community development, medical treatment and sanitation, poverty alleviation, disaster relief and post disaster re-construction, education capability development, training on practical skill, women centered projects and south to south exchanges. The influence of these NGOs can be evident in their work.

1. They promote Socialist ideological and ethical progress as well as social harmony.

2. They meet diversified demand of people and make up for governmental functions.

3. They boost the prosperity of education, science and technology and culture by giving play to the potentials of the talents and meeting the public demand for participating in public administration.

4. Some jobs are provided and employment pressure is relieved effectively.

18 Under China's official NGO policy, self organized entities, regardless of their missions and forms, are not entitled to receive
government funding. The Chinese business sector has not yet become a real resource for the nonprofit sector, let alone for Grassroots
organizations. The entire or at least major portion of the grassroots organization' income derived from foreign donations, foundations,
or NGOs. Cited in Ma Qiusha," GRASSROOTS ORGANIZATIONS IN CHINA : DEFINATIONS,CATEGORIES, AND
SIGNIFICANCE IN THE EMERGENCE OF CIVIL SOCIETY" INTER ASIA PAPPERS,WEB PAGE: http://www.uab..cat/grup-
recerca/interasia

${ }^{19}$ Yun Han," Research on Voluntary services in China”,Asian social Science ,Vol.5, No.4, April 2009 
5. Diplomatic relations are improved through further exchange with the overseas NGOs. ${ }^{20}$

There is no doubt that these NGOs are working to better the life of the Chinese people as a whole but it is also working as alternatives to the government/Party organizations involved in these same areas of social work. Though, these organizations have many restrictions/limitations imposed by the Communist Party of China, designated inspection departments.

In 2008, there were more than four hundred thousand registered nongovernmental organizations (NGOs),non- profit making organizations(NPO) or mass organizations in China in which a large percentage were self- organized youth organizations(SYOs). The number of SYOs and their scope of activities have gained great development in past thirty years. The blossoming of the SYOs reflected their significant functions and services in meeting multifarious youth needs and engage young people in interacting with other people, participating in social affairs, and involving in charitable activities. They are regarded as the second home of young people, a social venue for young people to participate in community affairs, and an organized group to voice out and protect the rights and welfare of vulnerable youth. They promote mutual help among young people with similar difficulties or problems, provide non-formal education for children of migrant workers, offer financial assistance to needy students, improve teaching facilities, and provide technical supports, information and services for young people. ${ }^{21}$

These youth organizations which are not directly funded by the State were doing better job as compared to the state funded organizations in serving common masses. These organizations are attracting youth towards them; however, these organizations have their own problems and restrictions. They are not independent to carry out works which were not favoring the Party's lines, such as issues of Human rights, youth discontent towards the economic reform, the real picture of economic disparity that has led youth of lower income group mostly graduates youth to stay together in urban cities. This group has been termed as “蚁族”22 (Ant Tribe). The living conditions of these youth s are very bad and there were continuous increase in numbers of ant tribes in China, talk against censorship etc.

The State sponsored youth organizations too had their problems such as:

1. Long term mechanism boosting development of volunteer organizations has not been formed. These voluntary organizations were the byproduct of mass movements.

2. There is no unified and standard management. Due to lack of proper management and coordination, these organizations could not achieve the desire targets and often led to duplication of work and wastage of time and resources.

3. Development of civilian organizations is restricted. The economic reform and opening up had created numerous social issues in general and youth issues in particular. The employment issues as central focus point. Each issue has its own importance and needed special or dedicated organizations to do research on the issues and come out with suggestions which can help the government to formulate certain policies to solve it. Each organization needed to register itself with the government. This was not easy in Chinese political structure, where politics is supreme.

4. Capital shortage has become a principle deterrent restricting development of voluntary services. Due to emergence of numerous issues, all issues cannot be given priorities, therefore, fund allocation to become a problem. In the absence of proper funding, these organizations had to face difficulties in implementation and execution of their projects.

5. Voluntary services lack judicial guarantee. No matter, how well the projects and its functioning were carried out, unless there is judicial recognition, these organizations were not well received among the masses.

6. Low level of social recognition also restricts development of voluntary services. The Chinese people especially the youth were less interested in joining or approaching voluntary organizations that are not recognized or less recognized in China. ${ }^{23}$

${ }^{20}$ Ibid

${ }^{21}$ Peng Ai, An Analysis of the Relationship between the Communist Youth League and Self-organized Youth organizations under organized social Construction system, China Youth Study, Beijing august 2010 (Chinese), cited and translation taken from Ngan-Pun Ngai,Sek- Yum Ngai and fang Wei," Revisiting China's Youth Policy, Forum21[Policy], http://www.youthpolicy.org/national/China_2011_Youth_Policy_Situation_Article.pdf downloaded on 22/12/2015 at 3;19 pm

${ }^{22}$ 蚂蚁族 :并不是一种昆虫族群, 而是“80 后”一个鲜为人知的庞大群体——“学毕业生低收入聚居群体”, 指的是毕业后无 法找到工作或工作收入很低而聚居在城乡结合部的大学生”(Ant tribes are not the groups of ants but the term has been coined for the 80s and 90s youth who had recently graduated from the universities and are in low income group and staying in urban fringe of the cities) “什么 是 蚂蚁族 https://www.cqdai.com/cqzx/touzilicai/201512152460.html accessed on 27/1/17

${ }^{23}$ Yun Han,” Research on Voluntary services in China”,Asian social Science ,Vol.5, No.4, April 2009 
In the Socialist Market Economy phase, the government sponsored youth organizations such as Communist Youth League too have come out with Party's sponsored volunteers and services. Therefore, the international and private organizations too have become some way or other medium of youth participation in China and have compelled the Party's organizations to chart new strategies to counter the emerging NGOs, GONGOs and grassroots organizations in socialist market economy. These organizations are in no way threat to the Communist Youth League of China in near future but it has posed challenges to its existing status of a link organization between the Youth and the Communist Party of China.

Internet has become the most frequently used mode of youth political participation in the recent years. Although, Internet arrived in China only in 1987, however, the post Tiananmen Square period witnessed a rapid increase in the numbers of netizens in China. With strict regulation in physical assembly of the youth, the youth have taken to the social media platform to voice their social concern and contribute in the policy making of China. The likeminded youth have formed social media groups on the web and vigorously discussing on the topics such as politics, leadership and social issues, openly without fear of getting caught by the police or the state machinery. Web-Based Youth Self Organizations such as CAPE, Black Apple Youth, Four Institute facilitates youth in sharing information and helping youth to redefine the social relationship. Black Apple Youth, Four Institute online youth organizations/communities focus on social engagement by youth. They came up with campaigns for a meaningful winter holiday for social good. These organizations provide youth a platform to discuss domestics and foreign issues which had bearing on youth. Chinese internet youth population increases every year. These online communities are also involved in offline activities. As per the Kevin Lee, COO of China Yuthology and creator of genYchina.com, the emergence of new media technologies, youth in China are just receptive and responsive as youth in other countries to global concepts such as participatory culture and sharism. ${ }^{24}$ Meet up, Social engagement, Change maker, Open action etc. were some of the online activities carried out by the youth in China. As per the Oliver Ding, the co-founder of the FOUR Institute, the focus of the campaign was to create an open platform for encouraging extensive social participation and bringing local change-makers together to make difference. $^{25}$

Although there emerged number of youth organizations and youth associations, such as SYOs (self-organized youth organizations), in the era of market economy, these organizations could not cross the popularity and influence of the Communist Youth League of China. Right from Mao era till date, Communist Youth League has continued to enjoy the status of being sole youth work organization that assists in formulating relevant policies and in managing youth affairs. ${ }^{26}$ The Communist Youth League of China, thus, has had a profound experience of tackling youth issues in the past and still enjoys the trust of the youth.

With the adoption of the Market reform, it's not the market structure that has changed, on contrary; the reform has brought about decay in moral values of Chinese people, especially the youth. There had been frequent reports of crimes, snatching, murder and other anti-social activities in China. According to some survey and media data, the people involved in these are mostly youths aged between 15 to 35 years.

It has been observed by many scholars that the development of materialistic values among the Chinese people, rising inequality and ideological and attitudinal changes had great impact on the social structure of the Chinese Society. The rising frustration among those working in the government and the intellectual class of China too had become the cause of concern for the Communist Party of China. Intelligentsia is finding their status even below the street vendors as they believe that the street vendors are earning more than these people.

Unlike the pre- reform era, there was emergence of many traditional, non state sources of moral authority which became an important issue for the Party. The Party has been facing great problem in carrying forward the economic reform as well as keeping its political ideology intact in the Chinese people and specially in the youth. The concept of 'collectivism' has overtaken by the 'Individualism' in China. There seemed to be a complete mismatch of policy initiatives put forward by the Communist Party of China before and after the beginning of the economic reform, which sent confusing signals to the youth in particular. Corruption within the Party and the government was causing serious problems in society which was losing its ideological and moral compass. Therefore, the Party needed new strategies for control and development.

As has been said by Richard Baum in his concluding remark of one of his article said, "With the Communist Party's reputation for integrity and incorruptibility severely tarnished, with Marxist-Leninist visions no longer capable of inspiring young people, with alienation, crime, and corruption on the rise, with provincial leaders asserting their economic muscle, and ethnic tensions growing more volatile at the periphery, China's future political tranquility is by no means assured. And it remains to be seen whether a post-Deng Xiaoping generation of neo-authoritarian Chinese technocrats will prove more

24 Wang Yuanqian, "In China, Digital Activists are Starting to Meet up in Person"
http://www.theatlantic.com/china/archive/2013/03/in-china-digital-activists-are-starting-to-meet-up-in-person/274248/ acessed on $21 / 1 / 17$ at $3: 23 \mathrm{pm}$

${ }^{25} \mathrm{ibid}$

${ }^{26}$ Ngan-Pun Ngai,Sek- Yum Ngai and fang Wei, "Revisiting China's Youth Policy, Forum21[Policy], http://www.youthpolicy.org/national/China_2011_Youth_Policy_Situation_Article.pdf downloaded on 22/12/2015 at 3;19_pm 
adept than their elderly, autocratic predecessors at comprehending and coping with profound transformative forces presently at work both in China and in the world at large." ${ }^{27}$

With limited education and experience, a section of the youth had resort to illegal means to make money. Although the Communist Party of China has been making regular efforts to float youth role models so as to provide moral and ideological, large section of the Chinese people were motivated by material incentives and were keen become rich as soon as possible. In addition income gap between the rich and the poor, and inequality resulting from have given rise to social hostilities and conflict $^{28}$.

The Communist Youth League being the youth wing of the Communist Party of China has an inherent duty to propagate and implement objectives and policies of the Party. In order to counter challenges arising out of economic reform, the Party has repositioned itself according to the changing socio-economic environment. The mode and objectives of the Party's propaganda has also changed after the introduction of the Socialist Market economy in China.

\section{Conclusion:}

As we all know, the Change is inevitable and cannot be restricted to a particular areas or context and the same can be seen in fast Changing Chinese society. The widening of gap among the Children and parents, Various Political parties in China, leaders and its cadres, shaping of new values (good or bad or both) in Youth are pointing towards an uncertainty. The time has come to rethink on the Confucius teaching of "仁”。 Which talks about the benevolence and harmony and what exactly Communist Party of China is doing but it has to think more in the context of Changing society, advance technology and more informative Youth of China. Youth have more time and more access of the information. The Chinese family has started consulting their kids while taking decisions on family issues, when and how Chinese government will do-----! Therefore, it has now become very important for the Communist Youth League to think new strategies to intact and attract its youth, who are otherwise getting fascinated with the other new youth organizations in China.

\section{REFERENCES:}

1. Jieying Xi, "Introduction to Chinese Youth" in Jieying Xi, Yunxia Sun and Jing Jian Xiao(ed) Chinese Youth in Transition , Ashgate, Aldershot ,2006

2. Glen H.Elder,Jr."Adolescence in historical perspective", in JosephAdelson(ed).Handbook of Adolescent in psychology, John Wiley and sons, New york,1980,pp.40-16

3. 代小琳(Dai Xiaolin), 中国青年失业率 9\%攀新高 72\%失业者为长期失业 Zhongguo qingnian shiyelu 9\% pan xingao $72 \%$ shiyezhe wei changqi shiye The long term unemployment ratio of the youth has reached to a new height of $72 \%$ from $9 \%$ [EB/OL]。 http//news.xinhuanet.com/fortune/2005-05/24/content_299434.htm.

4. Rigas Arvantis, Pierre Miege and Zhao wei, "A Fresh Look at the Development of a Market Economy in China" China Perspectives, in http://Chinapaperspectives.revues.org/564 downloaded at 1:10pm on 16/2/2016

5. 中国青少年发展状况 --------统计数据 分析报告（2005）中国青年研究，2001（1） (Statistical data analysis report on status of China's youth development -------- (2005) China Youth Research ,2001(1)

6. Data taken from 团史展览馆 ( League Historical Archive),http://www.gqt.org.cn/695/gqt_tuanshi/gqt_ghlc/tdjs/ accessed at 5:22pm on 15/6/16

7. "Safety first: China youth rush to grab govt jobs" from All China Youth Federation News, December25, 2009 http://www.acyf.org.cn/2009-12/25/content_3315284.htm acessed on 28/1/17 at 3:23pm

8. 俞敏洪(Yu Minhong); born 15 October 1962 in Jiangyin, Jiangsu) is the founder and current CEO of New Oriental Education \& Technology Group Inc. 新东方教育科技集团), and a member of the central committee of China Democratic League. As the owner of one of the largest private educational services, $\mathrm{Yu}$ is known as the "richest teacher in China", and "Godfather of English Training".[1] On Hurun Report's China Rich List 2013, he had an estimated wealth $\$ 1.1$ billion and was ranked No. 245 on the list.

9. 马云(Ma Yun); born September 10, 1964)is a Chinese business magnate and philanthropist. He is the founder and executive chairman of Alibaba Group, a family of successful Internet-based businesses. He is the first mainland Chinese entrepreneur to appear on the cover of Forbes. As of November 2014, he is the richest man in China (Hong Kong not included) and 18th richest person in the world, with an estimated net worth of $\$ 24.1$ billion, according to Forbes. https://en.wikipedia.org/wiki/Jack_Ma downloaded at 4;39pm on 11/1/16

${ }^{27}$ Richard Baum, "Political Stability in Post-Deng China: Problems and Prospects “Asian Survey, Vol.32, No. University of California Press, June,1992,pp.505

${ }^{28}$ Kuotsai Tom Liou,"State-society Relations in Post -Mao Chinese Economic Reforms: Changes and Challenges", International Journal of Economic development, Vol2(1),2000,pp142 
10. Yang JingYun, Li GongYi,et al, "Exploring the question of College students' Road of Growth", Chinese Education, Vol.23.No.1 spring1990.

11. Xue-liang Ding, "Disparity between idealistic and instrumental Chinese reforms" Asian Survey , Vol.28(II), November 1988, P.824

12. 叫郭正（Jiao Guozheng）,"碰破发展的出国留学工作”(Flourishing development of the work of sending out overseas students"), 中国高等教育 9Higher education in China, Beijing),No.12(1998), pp.6-8 in Higher Education in China, research materials from people's University,no.2,1999,p.72

13. "China to Improve Service for Returned Students," Xinhua General News Service, March13, 1992.

14. “关于在外留学人员有关问题的通知”, (Notification on related questions concerning scholars overseas”), cited in David Zweig, Chen Changgui and Stanley Rosen, "Globalization and Transnational Human capital: Overseas and Returnee scholar to China*" The China quarterly, Vol.179,September 2004,p.739

15. For details please see October 12,1992 江泽民 Jiang Zemin 在中国共产党的十四次全国代表大会上的报告 $<<$ 加快 改革开放和现代化建设步伐夺取有中国特色社会主义事业的变大胜利》 zai zhongguo gongchandang de (Jiang Zemin speech at the fourteenth party congress<<Deepening of reform and modernization will bring great advantage in task of establishing socialism with Chinese Characteristics $>>$ Zhonggup gongchandang lici quanguaodaibiaodahuishujuku 中国共产党历次全国代表大会数据库(Data base of all previous Congress of the Party congress)http://cpc.people.com.cn/GB/64162/64168/64567/65446/4526308.html accessed at 5:15pm on 15/4/16 lbid.

16. Wu Junfei, "Rise of the Communist Youth League" Economic and Political Weekly, March25,2006

17. Under China's official NGO policy, self organized entities, regardless of their missions and forms, are not entitled to receive government funding. The Chinese business sector has not yet become a real resource for the nonprofit sector, let alone for Grassroots organizations. The entire or at least major portion of the grassroots organization' income derived from foreign donations, foundations, or NGOs. Cited in Ma Qiusha," GRASSROOTS ORGANIZATIONS IN CHINA : DEFINATIONS,CATEGORIES, AND SIGNIFICANCE IN THE EMERGENCE OF CIVIL SOCIETY" INTER ASIA PAPPERS,WEB PAGE: http://www.uab..cat/grup-recerca/interasia

18. Yun Han," Research on Voluntary services in China”, Asian social Science ,Vol.5, No.4, April 2009 Ibid

19. Peng Ai, An Analysis of the Relationship between the Communist Youth League and Self-organized Youth organizations under organized social Construction system, China Youth Study, Beijing august 2010 (Chinese), cited and translation taken from Ngan-Pun Ngai,Sek- Yum Ngai and fang Wei," Revisiting China's Youth Policy, Forum21[Policy], http://www.youthpolicy.org/national/China_2011_Youth_Policy_Situation_Article.pdf downloaded on 22/12/2015 at 3;19 pm

20. 蚂蚁族 :并不是一种昆虫族群，而是“80 后”一个鲜为人知的庞大群体一一大学毕业生低收入聚居群体”，指的是毕 业后无法找到工作或工作收入很低而聚居在城乡结合部的大学生”(Ant tribes are not the groups of ants but the term has been coined for the 80 s and 90 s youth who had recently graduated from the universities and are in low income group and staying in urban fringe of the cities) “"什么 么 是 蚂蚁 族 https://www.cqdai.com/cqzx/touzilicai/201512152460.html accessed on 27/1/17

21. Yun Han," Research on Voluntary services in China”,Asian social Science ,Vol.5, No.4, April 2009

22. Wang Yuanqian, "In China, Digital Activists are Starting to Meet up in Person" http://www.theatlantic.com/china/archive/2013/03/in-china-digital-activists-are-starting-to-meet-up-inperson/274248/ acessed on 21/1/17 at 3:23pm lbid

23. Ngan-Pun Ngai,Sek- Yum Ngai and fang Wei, "Revisiting China's Youth Policy, Forum21[Policy], http://www.youthpolicy.org/national/China_2011_Youth_Policy_Situation_Article.pdf downloaded on 22/12/2015 at $3 ; 19$ pm

24. Richard Baum, "Political Stability in Post-Deng China: Problems and Prospects "Asian Survey, Vol.32, No. University of California Press, June,1992,pp.505

25. Kuotsai Tom Liou,"State-society Relations in Post -Mao Chinese Economic Reforms: Changes and Challenges", International Journal of Economic development,Vol2(1),2000,pp142

\section{Author' biography:}

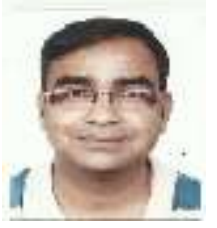

Currently Rakesh Kumar is an Assistant Professor in Chinese studies in School of Language, Literature and Culture Studies, Jawaharlal Nehru University, New Delhi, India. He did his Ph.D from the Center for Chinese and Southeast Asian Studies, JNU. He has authored book title: Politics \& Youth In Post-Mao China: A Case Study of Communist Youth League. His academic Interests are Asian Studies, Chinese Culture, social theories and international relation. 